\title{
ANALYSIS AND CARTOGRAPHIC MODELING OF THE STRUCTURE OF THE LAND FUND IN HOROKHIV DISTRICT OF VOLYN REGION
}

I. P. Kovalchuk, $P h D$ in geography, professor, head of the chair of geodesy and cartography in National University of Life and Environmental sciences of Ukraine T. S. Pavlovska, $P h D$ in geography, associate professor of the chair of physical geography in Lesya Ukrainka Eastern European National University

Yu. V. Biletskyi, PhD in biology, associate professor of the chair of physical geography in Lesya Ukrainka Eastern European National University

O. V. Rudyk, senior lecturer of the chair of geodesy, Earth ordering and cadaster in Lesya Ukrainka Eastern European National University

V. V. Gashynska, student of 3-rd year of the faculty of geography in Lesya Ukrainka Eastern European National University

e-mail:kovalchukip@ukr.net

pavlovska2011@gmail.com

Key words: GIS modeling, plowing coefficient, landscape and ecological area optimization, amount of forests, agriculturally used areas and semi-natural areas, the level of agricultural development, farmland plowing, structure of the land fund.

Relevance of the topic. On the one hand, there is an increasing disbalance between the aspiration for economic growth, and on the other hand the preservation of natural environment as a basis and a necessary condition for ecologically safe existence of humanity. Regarding this, the problem of the ecologization of human livelihood, in particular in the realm of land use, becomes ever more relevant in recent times $[1,2]$.

As it is known, agricultural development has an especially big influence on natural landscapes, as it implies drawing large areas of natural ecosystems in economic utilization. Besides, imperfection of agricultural practices and land resources management, together with inconsistency of agricultural activities with 
modern climate changes and the transformations of other components of natural environment sharpen the problems of land resources utilization.

Agricultural development is one of the major factors of transformation of the landscapes of Volyn region, especially its forested-steppe part. Relatively high productivity of soils in this area together with relatively small potential of mineral, forest and other resources have determined the wide-scale agricultural development of its land resources. Horokhiv district is not an exception, as the quality of its lands promoted their active and long-term agricultural utilization.

Analysis of recent publications. Presently there are plenty of scientific works of domestic and foreign scientists dedicated to the problems of the rational utilization of land fund. The issues of the optimization of land use structure in Ukraine, including the environmental and economic aspects of the formation of well-balanced systems of agricultural land use are considered in the works of D. I. Babmindr, M. O. Bagorko, O. F. Balatskyi, I. K. Bystriakov, P. P. Borschevskyi, V. M. Budziak, S. Yu. Bulygin, S. V. Bereziuk, R. I. Bespalko, M. S. Bilan, Yu. D. Bilyk, S. M. Volkov, V. V. Horlachuk, V. I. Horshchar, R. S. Grabovsky, G. I. Greschuk, M. R. Grytsina, A. V. Gutorov, G. D. Gutsulyak, A. S. Danilenko, B. M. Danylyshyn, V. Ye. Dankevich, D. S. Dobryak, S. I. Doroguntsov, J. M. Dorosh, O. P. Kanash, A. I. Kovaliv, I. P. Kovalchuk, A. V. Konoplyov, V. M. Krivov, P. F. Kulinich, A. S. Lisetskii, Yu. V. Lobunko, VA Mazur, M. S. Malanchuk, Yu. P. Manko, L. A. Marmul, A. G. Martin, V. V. Medvedev, T. B. Nagirniak, L. Ya. Novakovskii, S. P. Palamarchuk, R. M. Panas, Z. E. Pankov, A. L. Popova, I. D. Primak, N. M. Ridey, F. S. Sayyko, I.O. Sidorenko, V.P. Sitnik, A.Ya. Sokhnich, R. M. Stepin, O.G. Tarariko, V.M. Tregobchuk, A. M. Retiak, N. A. Tretiak, R. A. Tretiak, M. Fedorov, M. A. Khvesik, A. V. Khodakivska, S. Yu. Khrischuk, V. P. Tsemko, L. A. Shashula, O. I. Shkuratov and other scientists [1-8].

The current state of land resources and features of land use in the Volyn region were studied by Yu. M. Andreychuk, V. Yu. Voloshin, O. L. Dymshits, B. S. Zhdanyuk, F. V. Zuzuk, Z. K. Karpyuk, R. E. Kacharovsky, I. P. Kovalchuk, L. K. Koloshko, T. A. Knyazkova, N. M. Lischuk, Y. O. Molchak, T. S. Pavlovska, R. M. Panas, S. V. Polyansky, A. G. Potapova, O. V. Rudyk, Yu. S. Schchurko and others 
[4-6]. However, the problems of the ecologization of agricultural land use require further studies.

The aim and tasks of the research. The aim of this research is the analysis of present land use structure of Horokhiv district of Volyn region. To achieve this aim, the following tasks were accomplished: 1) analysis of the history of the researches on ecological problems of land use, including the agricultural one, in Ukraine and in Volyn region; 2) analysis of the physical-geographical conditions of Horokhiv district as a factor of the formation of modern structure of its land fund; 3 ) identification of the parameters of the land fund structure of the studied administrative district; 4) determination of the level of its agricultural development, the coefficients of cultivation of the territory, the cultivation of agricultural land, the share of forested areas, the ratio of natural and economically developed lands; 5) cartographic modeling of the state of land resources of the study area.

Materials and methods of research. The literary and Internet sources have been used, as well as the data form 6-zem of the General Directorate of the State Cadaster Office in the Volyn region (data as of 01.01.2016). Such research methods as comparative-geographical, mathematical, geoinformation modeling (using MapInfo Professional 8.0 SCP) have been applied.

Presentation of the main material and the substantiation of the results of the study. Horokhiv district is located in the southern part of the Volyn region. Its area is $1122 \mathrm{~km}^{2}$ (5.6\% of the region area). The district includes 2 urban, 2 settlement and 36 village councils.

On 01.01.2016 agricultural lands prevails in the structure of the land fund of Horokhiv district. The share of the agricultural lands is 79\%. Forests and other forested areas cover $10.5 \%$ of the territory, about $4 \%$ of it is covered by both built-up areas and open wetlands, $1.8 \%$ are under surface waters, and the smallest percentage $(0.3 \%)$ is occupied by open land without vegetation cover or with insignificant vegetation (Fig. 1). 


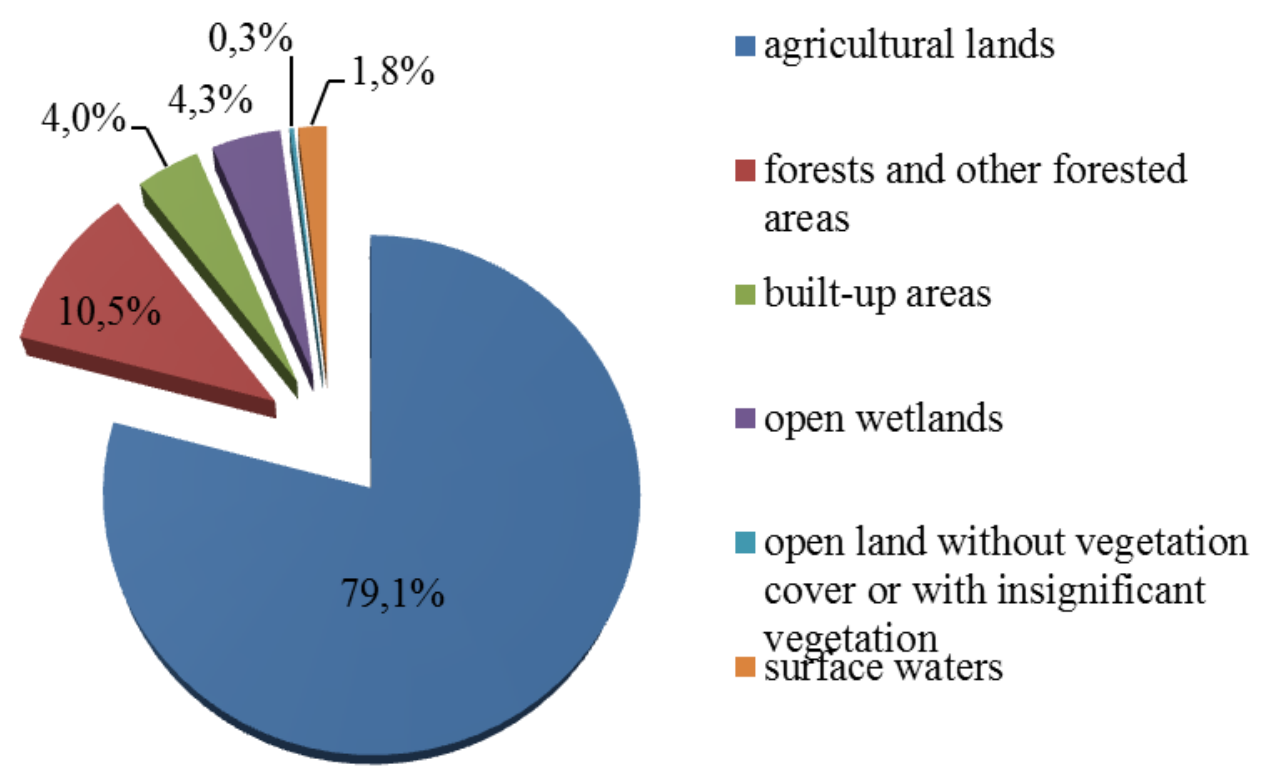

Fig. 1. Structure of land fund of Horokhiv district on 01.01.2016.

The highest shares of agricultural land are typical to Berezhanka (95\%), Zhabche, Pustomyty (both 94\%), Myrne (93\%), Vatyn, Myrkiv, Myhlyn (all 91\%), Hubyn the First and Skirche village councils (both 90\%), since in these areas, in comparison with other administrative units of the district, morphological and morphometric parameters of the terrain are more suitable for agricultural cultivation, while forested and floodplain landscapes and surface waters occupy smaller areas. The smallest shares of agricultural lands are typical to land fund of Horokhiv (20\%) and Urban-type settlement of Mar'yanivka (31\%), since large areas there are occupied by built-up lands.

The area of forested lands in the most of administrative units of Horokhiv district do not exceed 10\%. The largest area of such kind is in the southern part of the district, reaching the maximum values in the Pisky village council-41\% (Fig. 2). 


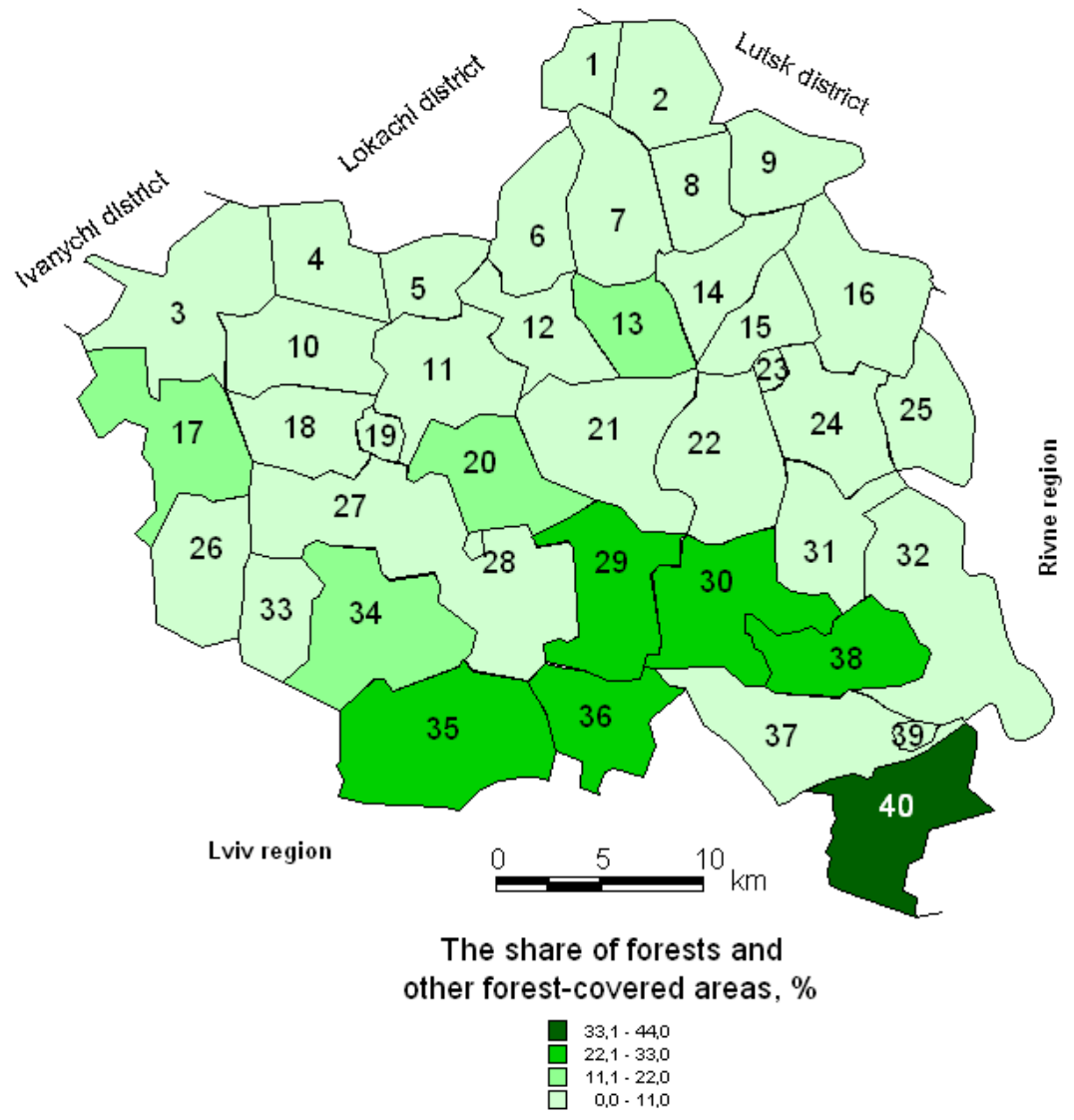

Administrative units of Horokhiv district:

village councils: 1 - Vatyn, 2 - Skirche, 3 - Pidberezzya, 4 - Rachyn, 5 - Lemeshiv, 6 Pustomyty, 7 - Myrne, 8 - Berezhanka, 9 - Myhlyn, 10 - Myrkiv, 11 - Skobelka, 12 Tereshkivtsi, 13 - Vil'khivka, 14 - Shklyn', 15 - Hubyn the First, 16 - Uhryniv, 17 Pechykhvosty, 18- Pirvanche, 20 - Kholoniv, 21 - Zvynyache, 22 - Novosilky, 24 - Kolodezhe, 25 - Zhabche, 26 - Kvasiv, 27 - Tsehiv, 29 - Halychany, 30 - Lobachivka, 31 - Horishnje, 32 Peremyl', 33 - Zhuravnyky, 34 - Brany, 35 - Buzhany, 36 - Skryhove, 37 - Merva, 38 Smolyava, 40 - Pisky; towns: 19 - Horokhiv, 39 - Berestechko; urban-type settlements: 23 Senkevychivka, 28 - Mar'yanivka.

\section{Fig. 2. Percentage of forested lands in Horokhiv district on 01.01.2016.}

The third position in the land use structure of the Horokhiv district is open wetlands. The largest areas of marshes are typical to Brany, Buzhany, Zhuravnyky, Merva, Peremyl', and Tsehiv village councils. There are no swamps in the Zhabche village council, urban-type settlement Senkevychivka and town of Berestechko.

The highest share of build-up areas is typical to Buzhany and Tsehiv village councils and the town of Horokhiv. The smallest areas of built-up land are inherent to Berezhany, Myrkiv and Myhlyn village councils. 
The largest area of the water mirror is in the Peremyl' and Kholoniv village councils, but in the Pustomyty village council, urban-type settlement of Senkevychivka and town of Horokhiv there are no surface waters.

The smallest share in the structure of the land fund of the study area is occupied by lands without plant cover or with insignificant vegetation cover. The largest areas of this category of land are in the Brany and Tsehiv village councils, since large areas here are covered by outlets of brick and tile raw materials. This kind of land is absent in Berestechko, Skirche, Pirvanche, Mykhlyn, Lemeshiv, Halychany and Berezhany village councils.

The natural mosaic of landscapes of Horokhiv district is mostly being disturbed by the agricultural land use. The share of agricultural lands in the structure of the land fund of the study area is $77 \%$. This share is the highest in rural councils of the northern part of the district (Fig. 3).

The total share of the arable lands in the Horokhiv district is $67.11 \%$, which characterizes the situation as ecologically unfavorable (shares at the level of 60-80\% are considered unfavorable, $25-60 \%$ are conditionally favorable and less than $25 \%-$ favorable [3]). The highest share of arable land (over 80\%) in the structure of the land fund is characteristic of the Berezhany, Vatyn, Hubyn the First, Zhabche, Lemeshiv, Myrne, Pustomyty, Skirche rural councils. The least developed are the territories of the town of Horokhiv (almost 20\%), Berestechko, urban-type settlement of Mar'yanivka (about 30\%) and Buzhany village council (almost 39\%) (Fig. 4).

Regarding agricultural land cultivation, this index reaches $87 \%$ in the Horokhiv district. The largest share of arable land (over 90\%) in the structure of these lands is typical to Berezhanka, Vatyn, Hubyn the First, Zhabche, Zhuranyky, Lemeshiv, Myrne, Myrkiv, Peremyl’, Pechyhvosty, Pisky, Rachyn, Skirche, Skobelka, Tereshkivtsi, Uhryniv, Tsehiv village councils (Fig. 5). As for the agricultural lands of Horokhiv and urban-type settlement of Mar'yanivka, besides arable land, there are no other categories of land (pastures, grasslands, perennial plantations). The least shares of arable land are typical to the Kholoniv and Skryhove village councils, due to the presence of significant areas of grasslands and pastures on the waterlogged floodplains of the Sudylivka and Lypa rivers, which are tributaries of the Styr River. 
As it is known, ecological conflictlesness, high productivity, aesthetic attractiveness of the territory are achievable, if there are natural and semi-natural lands there, and their share should be $60 \%$ optimally, while $35-40 \%$ is the minimum allowable value [8]. Horokhiv district has a small share of natural and semi-natural territories $-24 \%$. Among all administrative units of the study area, it is the highest in Skryhove (53\%), Pisky (48\%), Buzhany (44\%) Halychany (42\%), Lobachivka (41\%) rural councils, and the smallest are in urban-type settlement of Senkevychivka (1\%), Mar'yanivka (6\%), Berezhanka (6\%), Myrne (7\%), Lemeshiv (8\%), Vatyn (9\%), Hubyn the First (9\%) village councils (Fig. 6).

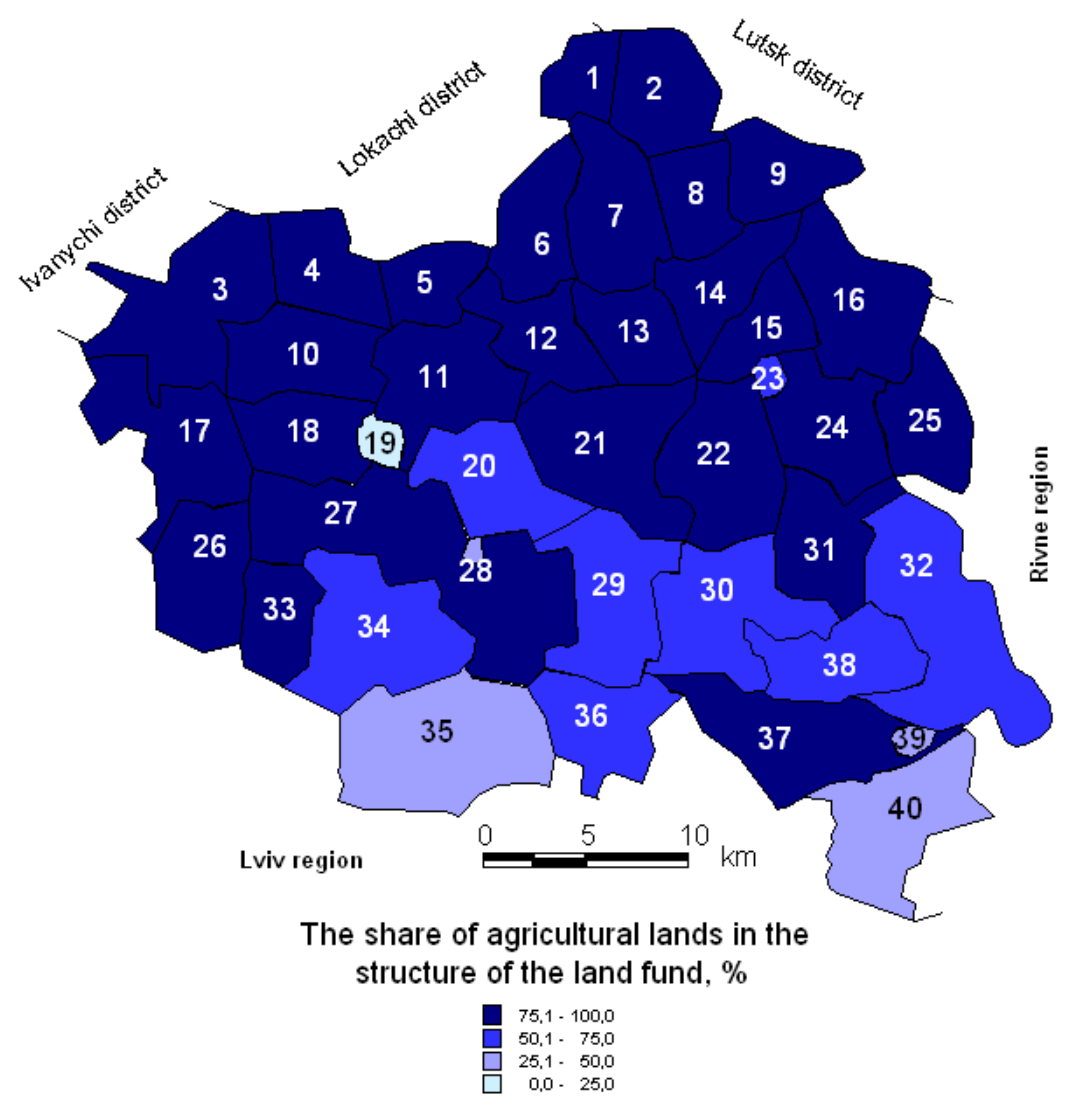

See the legend for the map on Fig. 2.

Fig. 3. Agricultural development in Horokhiv district on 01.01.2016. 


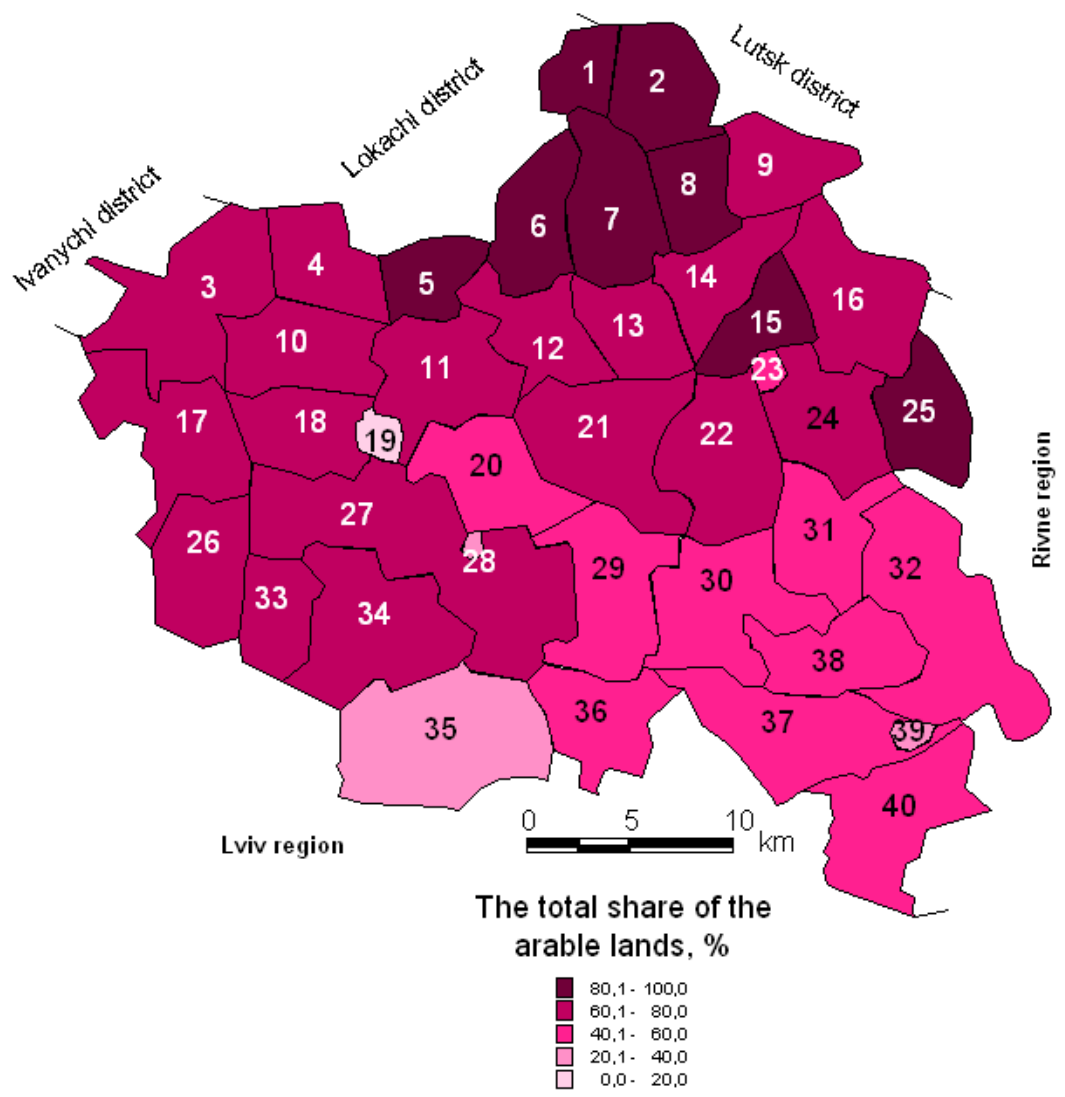

See the legend for the map on Fig. 2.

Fig. 4. Shares of arable land in land fund structure of Horokhiv district on

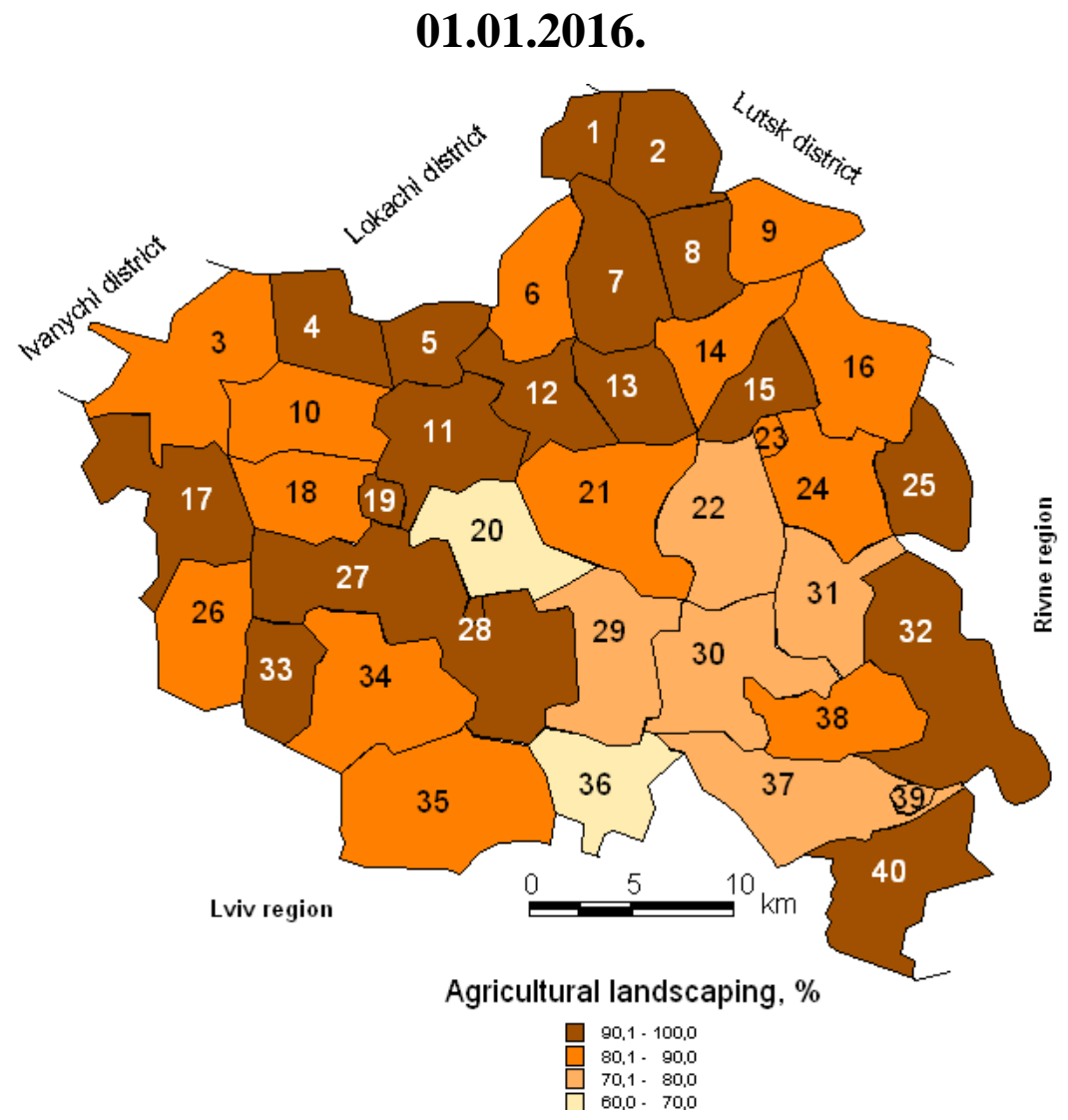

See the legend for the map on Fig. 2.

Fig 5. Shares of arable land in agricultural lands of Horokhiv district on 01.01.2016. 


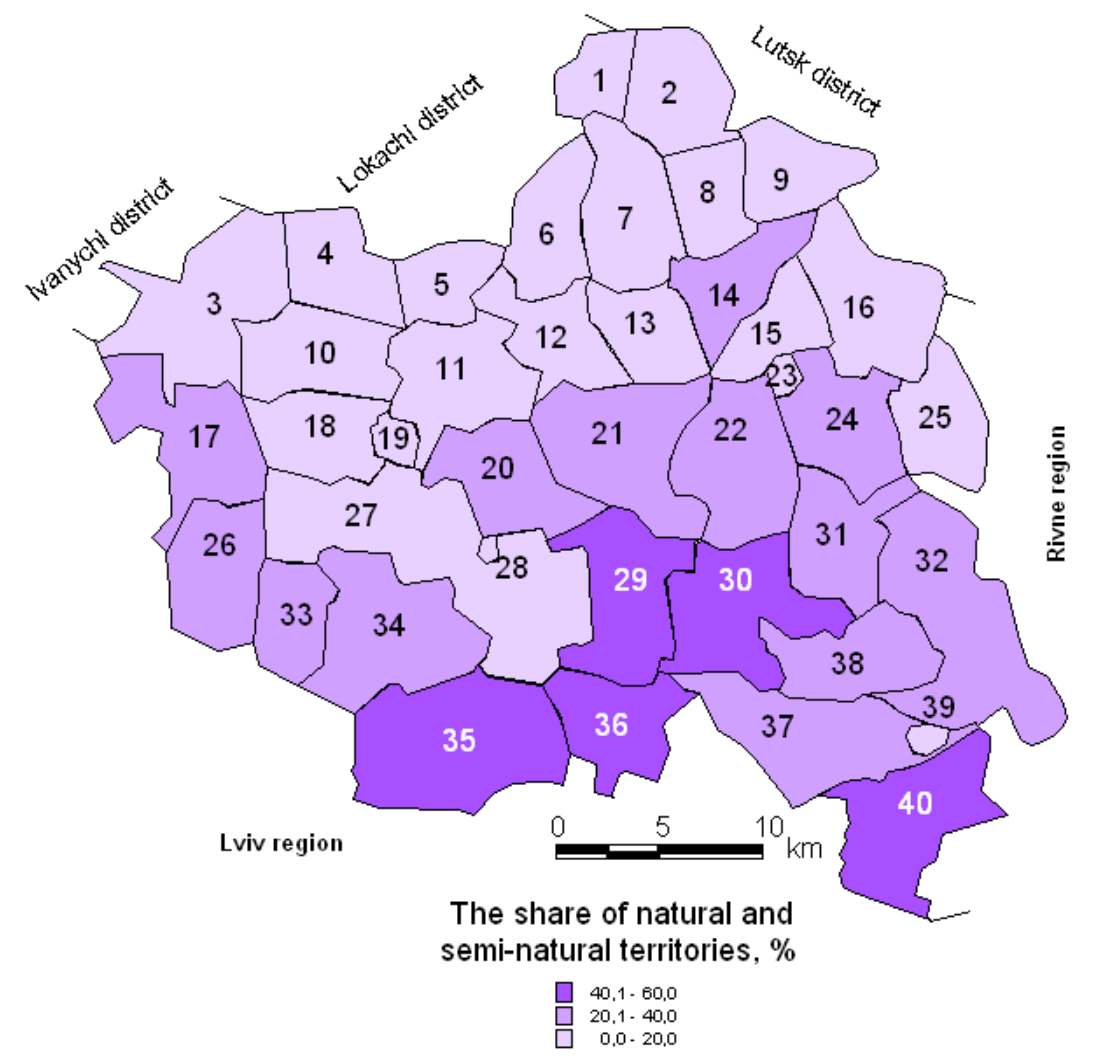

See the legend for the map on Fig. 2.

Fig 6. Shares of natural and semi-natural lands of Horokhiv district on 01.01.2016.

Summary. Horokhiv district is characterized by extremely unfavorable structure of land that is proved by a small share of natural and semi-natural areas (24\% in general, and less than $10 \%$ in many administrative units of the district), high shares of arable lands $(67.11 \%$ as a whole for the district, and more than $80 \%$ in eight village councils) and agricultural land cultivation ( $87 \%$ for the area, and more than $90 \%$ for half of the administrative units of the area). The situation characterized by a high degree of agricultural development of the territory (77\%) is due to the presence of fertile land here, the long history of settlement and the long dominance of farming traditions. For more detailed ecological diagnostics of the area of Horokhiv district, it is necessary to assess the ecological balance coefficients of its territorial structure using remote sensing data and laboratory studies. However, the obtained information can altogether be useful in the development of measures to optimize the landscape and environmental structure of the land fund of the united territorial communities, which are created within the new administrative-territorial structure, to provide for the reproduction of soil fertility potential, to preserve the biotic and landscape diversity of the region. 


\section{REFERENCES}

1. Bahorka M. O. Kompleksna ekoloho-ekonomichna otsinka zemlekorystuvannia v Ukraini / M. O. Bahorka // Naukovyi visnyk Mizhnarodnoho humanitarnoho universytetu. - Odesa, 2017. - Vyp. 27. - S. 55-59.

2. Bilan M. S. Osnovni aspekty rozvytku ekolohizatsii silskohospodarskoho zemlekorystuvannia Ukrainy [Elektronnyi resurs] / M. S. Bilan. - Rezhym dostupu : https://www.sworld.com.ua/konfer28/192.pdf

3. Ekolohichni problemy zemlerobstva [I. D. Prymak, Yu. P. Manko, N. M. Ridei, V. A. Mazur, V. I. Horshchar, O. V. Konoplov, S. P. Palamarchuk, O. I. Prymak; za red. I. D. Prymaka]. - Kyiv : Tsentr uchbovoi literatury, 2010. - 456s.

4. Kovalchuk I. P. Heoinformatsiino-kartohrafichne modeliuvannia struktury zemelnoho fondu oblasnoho rehionu / I. P. Kovalchuk, B. S. Zhdaniuk, Yu. M. Andreichuk // Chasopys kartohrafii. - Kyiv : KNU imeni Tarasa Shevchenka, 2016. - Vyp. 16. - S. 48-61.

5. Pavlovska T. S. Struktura zemelnykh uhid v landshaftno-ekolohichnii orhanizatsii terytorii Volynskoi oblasti / Pavlovska T. S. // Heopolytyka y эkoheodynamyka rehyonov. - Symferopol, 2014.- T. 10. - Vыр. 2. - C. 697-704.

6. Pavlovska T. S. Suchasna struktura zemlekorystuvannia Lutskoho raionu: ahrolandshaftnyi aspekt / T. S. Pavlovska, O. V. Rudyk, V. U. Voloshyn // Science and Education a New Dimension. Natural and Technical Sciences. Budapest. - V(14), Issue: 132. - 2017. - S. 20-23.

7. Pashkov I. A. Systemni osnovy staloho zemlekorystuvannia v Ukraini [Elektronnyi resurs] / I. A. Pashkov. - Rezhym dostupu : http://www.nbuv. gov.ua/ portal/ natural/vznu/eco/2009_1/149.pdf.

8. Popova O. L. Ekodiahnostyka pryrodno-hospodarskoi orhanizatsii terytorii Ukrainy: ahrolandshaftnyi aspekt [Elektronnyi resurs] / O. L. Popova. - Rezhym dostupu: archive.nbuv.gov.ua/portal/soc_gum/ep/2012_3/7_Pop.pdf 